\title{
A new feedback mechanism linking forests, aerosols, and climate
}

\author{
M. Kulmala ${ }^{1}$, T. Suni ${ }^{1}$, K. E. J. Lehtinen ${ }^{1}$, M. Dal Maso ${ }^{1}$, M. Boy ${ }^{1}$, A. Reissell ${ }^{1,2,3}$, Ü. Rannik ${ }^{1}$, P. Aalto ${ }^{1}$, \\ P. Keronen ${ }^{1}$, H. Hakola ${ }^{2}$, J. Bäck ${ }^{4}$, T. Hoffmann ${ }^{5}$, T. Vesala ${ }^{1}$, and P. Hari ${ }^{4}$ \\ ${ }^{1}$ University of Helsinki, Department of Physical Sciences, P.O. Box 64, FIN-00014, University of Helsinki, Finland \\ ${ }^{2}$ Finnish Meteorological Institute, Sahaajankatu 20 E, FIN-00880 Helsinki, Finland \\ ${ }^{3}$ University of Helsinki, Department of Chemistry, P.O. Box 55, FIN-00014 University of Helsinki, Finland \\ ${ }^{4}$ University of Helsinki, Department of Forest Ecology, P.O. Box 27, FIN-00014, University of Helsinki, Finland \\ ${ }^{5}$ Institute of Spectrochemistry and Applied Spectroscopy, Bunsen-Kirchhoffstr. 11, D-44139 Dortmund, Germany
}

Received: 8 October 2003 - Published in Atmos. Chem. Phys. Discuss.: 4 December 2003

Revised: 17 March 2004 - Accepted: 22 March 2004 - Published: 30 March 2004

\begin{abstract}
The possible connections between the carbon balance of ecosystems and aerosol-cloud-climate interactions play a significant role in climate change studies. Carbon dioxide is a greenhouse gas, whereas the net effect of atmospheric aerosols is to cool the climate. Here, we investigated the connection between forest-atmosphere carbon exchange and aerosol dynamics in the continental boundary layer by means of multiannual data sets of particle formation and growth rates, of $\mathrm{CO}_{2}$ fluxes, and of monoterpene concentrations in a Scots pine forest in southern Finland. We suggest a new, interesting link and a potentially important feedback among forest ecosystem functioning, aerosols, and climate: Considering that globally increasing temperatures and $\mathrm{CO}_{2}$ fertilization are likely to lead to increased photosynthesis and forest growth, an increase in forest biomass would increase emissions of non-methane biogenic volatile organic compounds and thereby enhance organic aerosol production. This feedback mechanism couples the climate effect of $\mathrm{CO}_{2}$ with that of aerosols in a novel way.
\end{abstract}

\section{Introduction}

In 2001, the Intergovernmental Panel on Climate Change (IPCC) estimated the global and annual radiative forcing due to greenhouse gases and aerosols, along with natural changes associated with solar radiation. Emphasis was placed on the complexity of the combined direct and indirect forcing from both aerosols and gases as well as on the importance of improving our understanding of the role each of these three individual components plays in an integrated system. Such knowledge would reduce the uncertainty in current estimates of radiative forcing and enable a better prediction of the ef-

Correspondence to: M. Kulmala

(markku.kulmala@helsinki.fi) fects of anthropogenic activity on global change. The most important issue to resolve is how the different components affecting radiative forcing interact with one another. Here we propose a mechanism that couples the effect of $\mathrm{CO}_{2}$ and aerosol particles on climate. This suggestion is based on connections among $\mathrm{CO}_{2}$-induced climate change, increased vegetation productivity, emissions of non-methane biogenic volatile organic compounds (BVOCs), and their ability to form aerosol particles.

\section{Background}

Aerosol particles affect the climate directly by reflecting or absorbing solar radiation and indirectly by acting as cloud condensation nuclei $(\mathrm{CCN})$. Either way, aerosols reduce the amount of solar radiation reaching the Earth's surface. Among the key questions in reducing the uncertainties relating to radiative forcing of particles are how they are formed, how they grow from clusters of a few molecules to CCN sizes $(>100 \mathrm{~nm})$, and how they form cloud droplets. Formation of nanometre-sized aerosol particles and their subsequent growth to $\mathrm{CCN}$ sizes have been observed frequently in the continental boundary layer all around the world (Kulmala et al., 2004): from sub-arctic Lapland to the remote boreal forest in southern Finland (Mäkelä et al., 1997) and from central Europe (Birmili and Wiedensohler, 2000) to rural United Kingdom (Coe et al., 2000). Once formed, clouds influence Earth's radiation budget extensively by contributing to albedo and greenhouse effects. With global warming, cloud properties are likely to change due to warmer and moister conditions and also evidently due to increased aerosol particle concentrations from both primary (such as wind-generated sea spray) and secondary processes (from biogenically and anthropogenically influenced gas-toparticle conversion processes). The formation and growth of 


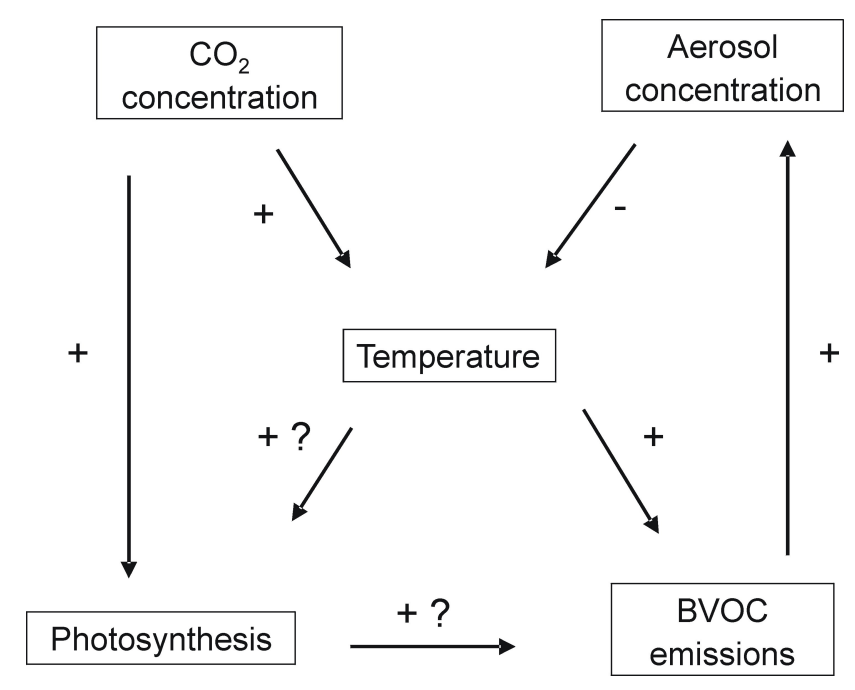

Fig. 1. Schematic figure of coupling of atmospheric $\mathrm{CO}_{2}$ concentration, assimilation of carbon by vegetation productivity (ecosystem gross primary production GPP), emission of biogenic volatile organic compounds (BVOCs), and aerosol particle concentration with atmospheric temperature. Increased $\mathrm{CO}_{2}$ concentration will increase temperature (+) and vegetation productivity (+). Increased temperature will enhance BVOC emissions $(+)$ and probably also plant productivity (+?). Increased vegetation productivity may enhance BVOC emissions (+?). Increased BVOC emissions will enhance aerosol formation and growth and therefore also enhance aerosol and CCN concentrations (+). Enhanced aerosol and CCN concentrations will decrease temperature $(-)$ due to increased reflection of sunlight from low clouds back to space. This results also in the increase of diffuse radiation, which has a positive influence on photosynthesis (Gu et al., 2003).

aerosol particles are related to the properties and transport of air masses as well as to biological activity and depend in a highly non-linear way on concentrations of nucleating and condensing vapours, temperature and relative humidity (Kulmala et al., 2000, 2001; Mäkelä et al., 2002; O’Dowd et al., 2002).

Terpenoids, among the most important BVOCs emitted by the vegetation, are known to lead to aerosol formation through rapid reactions with atmospheric oxidants such as ozone $\left(\mathrm{O}_{3}\right)$, hydroxyl $(\mathrm{OH})$ radicals, and nitrate $\left(\mathrm{NO}_{3}\right)$ radicals (Seinfeld and Pandis, 1998). The products of these reactions possess low volatility due to various functional groups including, for instance, carboxylic acids. Therefore, they readily take part in gas-to-particle conversion processes (Atkinson, 2000; Calogirou et al., 1999). Plants synthesize terpenoids by two distinct pathways, the mevalonic acid (Bohlmann et al., 1998) and the 1-deoxy-D-xylulose-5phosphate (Lichtenthaler, 1999). The first route is attributed to production of terpenoids (such as some monoterpenes) that are stored in specialized storage tissues and whose emissions follow the ambient temperature (Fuentes et al., 2000). The latter pathway, involved, for instance, in synthesis of iso- prene and $\alpha$-pinene, is coupled with a variety of environmental variables such as $\mathrm{CO}_{2}$ concentration, temperature, or light intensity (Staudt and Bertin, 1998), and has been associated with carbon fixed immediately prior to synthesis (Loreto et al., 1996). Monoterpene emissions from boreal tree species such as Pinus sylvestris, Picea abies and Betula pubescens have also been attributed to light (Hakola et al., 2001; Janson, 1993; Schürmann et al., 1993). Recent measurements from Scots pine in Hyytiälä, southern Finland, showed a significant reduction in monoterpene emissions in dark conditions (Bäck et al., 2003) and suggest that both temperature and light play a role in controlling emission rates.

\section{Proposed mechanism}

Figure 1 shows the proposed mechanism and coupling among processes in forest ecosystems (vegetation productivity and BVOC emissions), aerosols, and climate. Photosynthesis drives ecosystem gross primary production (GPP), the difference between net ecosystem exchange of $\mathrm{CO}_{2}$ (NEE) and total ecosystem respiration (TER). In the boreal zone, photosynthesis occurs predominantly in sunlight during the growing season (Hari and Mäkelä, 2003) and is inhibited in winter (Ottander et al., 1995). A negative feedback exists between atmospheric $\mathrm{CO}_{2}$ concentrations and plant growth: Increasing $\mathrm{CO}_{2}$ concentrations accelerate photosynthesis which in turn consumes more $\mathrm{CO}_{2}$ (Lenton, 2000; Nemani et al., 2003). On the other hand, forest ecosystems also act as significant sources of atmospheric aerosols (Kulmala et al., 2001). Terrestrial vegetation contributes substantially to emissions of a variety of BVOCs (Fuentes et al., 2000) and newly formed particles in forested areas have been found to contain large amounts of organic material (O'Dowd et al., 2002). The ratio of BVOC emission to carbon assimilation is generally a few percent (Grace and Rayment, 2000; Guenther et al., 1995), and if increased $\mathrm{CO}_{2}$ concentrations enhance vegetation productivity, we suggest that emission of aerosol-forming BVOCs may increase and possibly modify the aerosol particle formation routes (Kulmala et al., 2001).

In order to be able to test our hypothesis of the connection between aerosol formation and forest ecosystem activity, we analysed six years of field measurement data from Hyytiälä, southern Finland $\left(61^{\circ} 51^{\prime} \mathrm{N}, 24^{\circ} 17^{\prime} \mathrm{E}, 181 \mathrm{~m}\right.$ above sea level). Measurement of aerosol formation and growth (Kulmala et al., 2001), of surface fluxes as well as of meteorological variables and trace gases (temperature, radiation, $\mathrm{O}_{3}$ etc.) have been performed continuously in Hyytiälä since 1996 (Vesala et al., 1998). Since the beginning of 2001, also BVOC concentrations in the air have been measured every third day (Hakola et al., 2003). We calculated formation rates for $3 \mathrm{~nm}$ particles (J3) as well as particle diameter growth rates (GR) directly from measured particle size distributions obtained with aerosol mobility spectrometers (Aalto et al., 2001). J3 varied between 0.02 and $2.3 \mathrm{~cm}^{-3} \mathrm{~s}^{-1}$, with 


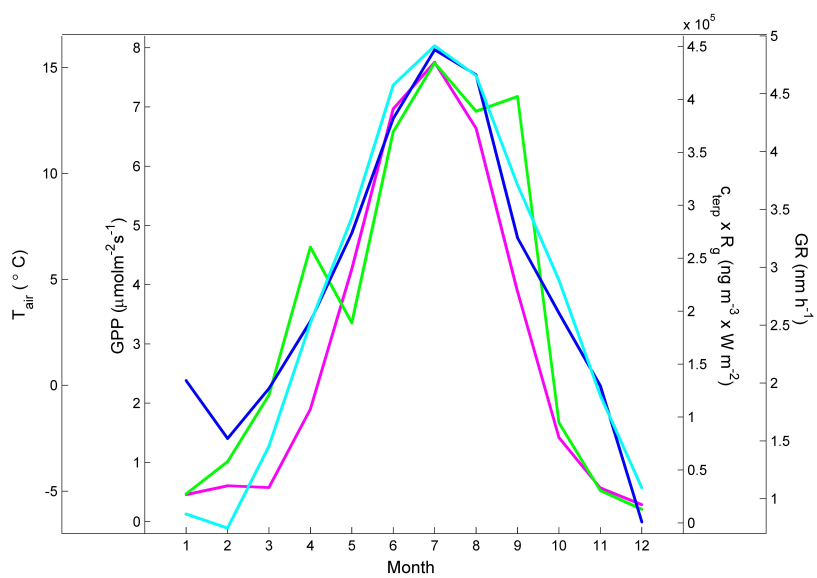

Fig. 2. Seasonal behaviour of GPP, growth rate, air temperature, and a proxy for BVOC oxidation products from $\mathrm{OH}$-reactions. Growth rate (GR) for all events (dark blue), gross primary production (GPP) (pink), sum of mean monoterpene concentrations ( $\left.c_{\text {terp }}\right)$ times global radiation $\left(R_{g}\right)$ (green), and air temperature $\left(T_{\text {air }}\right)$ (light blue). The points represent monthly means averaged over all years 1996-2001 (2001-2002 for terpenes).

a mean value of $0.36 \mathrm{~cm}^{-3} \mathrm{~s}^{-1}$. The GR were obtained from an analysis of the size distribution evolution of 361 particle formation events observed from 1996 to 2001. The GR varied between 0.1 and $14.2 \mathrm{~nm} / \mathrm{h}$, with a mean of $3.1 \mathrm{~nm} / \mathrm{h}$. GPP was calculated as NEE-TER; NEE was measured by the eddy covariance technique (Markkanen et al., 2001; Suni et al., 2003), and TER was modelled on the basis of nighttime NEE measurements. For more details of the site and corresponding measurement techniques, see e.g. Kulmala et al. (2001) and Suni et al. (2003).

The growth rate of nucleation-mode particles has a clear maximum in summer. Figure 2 shows the monthly mean values, averaged over 6 years, for GPP, GR and air temperature $\left(T_{\text {air }}\right)$. The figure also shows the monthly mean of the product of total monoterpene concentrations and global radiation $\left(R_{g}\right)$, which is used here as a proxy for the formation of BVOC oxidation products from OH-reactions. Similar annual behaviour of the different parameters is clearly visible. In particular, GR peaks the same way (maximum in July) as does the proxy for the $\mathrm{OH}$-oxidation products. The $\mathrm{OH}$ oxidation mechanism has recently been found to explain roughly $30-50 \%$ of the growth rates (Boy et al., 2003). Furthermore, GPP and $T_{\text {air }}$ show almost exactly the same seasonal behaviour, suggesting that both light- and temperaturedependent BVOC emissions play an important role in the particle formation and growth process.

Figure 3 shows the observed J3 from the same data set, together with the product of mean monoterpene and ozone concentrations, which serves as a proxy for the products of the ozonolysis of BVOCs. The monthly patterns of these vari-

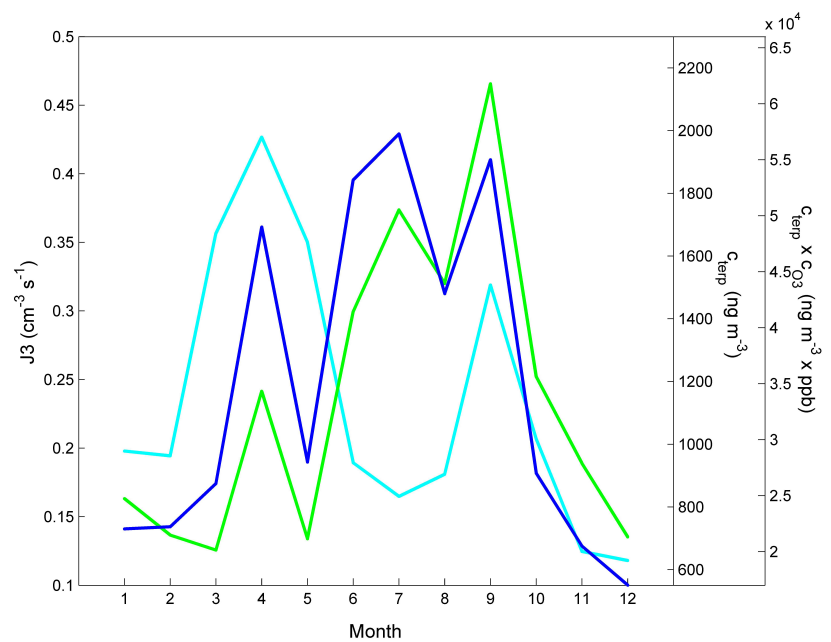

Fig. 3. Seasonal behaviour of formation rate, monoterpene concentrations, and a proxy for BVOC oxidation products from $\mathrm{O}_{3}$ reactions. Formation rate of $3 \mathrm{~nm}$-diameter particles $\mathrm{J} 3$ (light blue), mean monoterpene concentrations ( $\left.c_{\text {terp }}\right)$ (green), sum of mean monoterpene concentrations times mean $\mathrm{O}_{3}$ concentration. $\left(c_{\text {terp }} \times c_{\mathrm{O}_{3}}\right)$ (dark blue). The points represent monthly means averaged over all years 1996-2001 (2001-2002 for terpenes).

ables show some interesting similarities. In particular, both curves show similar peaks in spring and autumn. However, the summer peak visible in the ozonolysis product curve does not appear in J3. This is probably because particle formation typically occurs during cold air outbreaks within arctic or polar air masses (Kulmala et al., 2001; Nilsson et al., 2001), which are not common in summer months (June-August). In summer, sub-tropical air masses occur with high pre-existing aerosol concentrations, suppressing new-particle formation. The bimodal annual pattern of $\mathrm{J} 3$ is similar to the annual pattern of the frequency of nucleation events. For comparison, also the mean monoterpene concentration is shown in Fig. 3. This parameter exhibits its peak values significantly later during the year and the spring peak is less pronounced.

\section{Discussion}

The observed month-to-month patterns in Figs. 2 and 3 suggest firstly that the formation rate of new particles might also be linked with the rate of terpene reactions with $\mathrm{O}_{3}$ (Fig. 3) and secondly that the overall GR is correlated with the rate of terpene reactions with $\mathrm{OH}$ (Fig. 2). The first of these observations could be explained by the formation of very lowvolatility products from the ozonolysis reaction of certain terpenes as has been observed in several laboratory studies (Bonn and Moortgat, 2003; Hoffmann et al., 1998), and gains special relevance considering the increase of tropospheric ozone concentrations as a consequence of anthropogenic activities (Kanakidou et al., 2000). The second observation 
demonstrates the general importance of BVOC oxidation on particle growth and, hence, on $\mathrm{CCN}$ formation.

At the global scale, BVOCs are emitted from vegetation with a rate of about $1.2 \times 10^{15} \mathrm{gC}$ per year (Guenther et al., 1995 ), which is $\sim 2 \%$ of the estimated global carbon assimilation by terrestrial ecosystems (Grace and Rayment, 2000). Under present conditions, increased $\mathrm{CO}_{2}$ concentration will almost linearly increase $\mathrm{CO}_{2}$ assimilation (Farquhar and von Caemmerer, 1982), which is likely to lead to increased BVOC emissions as well. The increased concentrations of BVOCs will then have an important effect on atmospheric chemistry, for example on $\mathrm{O}_{3}$ formation (Seinfeld and Pandis, 1998), and particularly on the formation and growth of atmospheric aerosols (Kavouras et al., 1998). They will also enhance the condensational growth of small nuclei, and subsequently a larger fraction of aerosol particles will be able to grow to CCN sizes. Because of the uncertainties related to the coupling between ambient $\mathrm{CO}_{2}$ concentrations and BVOC emissions, we can consider two extreme scenarios: Firstly, assuming that no coupling exists, doubling of atmospheric $\mathrm{CO}_{2}$ concentration will not affect the global BVOC emission rates at all. Secondly, assuming complete coupling, doubling of atmospheric $\mathrm{CO}_{2}$ concentration will also double the emission rates. As a moderate estimate, we assume below that the increase in BVOC emissions will be $10 \%$. Note that we ignore the possible increase in BVOC emissions due to increased temperature, lengthened growing season, nitrogen fertilization, or increased leaf area index. These will make the increase stronger.

If we have $10 \%$ more condensable vapours due to an increase of $10 \%$ in BVOC emissions, the aerosol particles grow to $\mathrm{CCN}$ sizes in principle in roughly $10 \%$ shorter time and thus experience less scavenging by coagulation. However, since coagulation scavenging is a process leading to exponential decay in nucleation- mode number concentration and is strongly dependent on particle size (as a function of time), the effect of shorter growing times on the number concentration of $\mathrm{CCN}\left(c_{\mathrm{CCN}}\right)$ is actually considerably larger $-c_{\mathrm{CCN}}$ may increase by much more than $10 \%$. According to observed nucleation and growth events in a boreal forest (Kulmala et al., 2000, 2001), $c_{\mathrm{CCN}}$ will increase by a factor of 2 to 4 during an event (Kurtén et al., 2003). Since there are around 50 events per year (Kulmala et al., 2001), we can estimate that $30-60 \%$ of average total $c_{\mathrm{CCN}}$ stems from formation and growth events in the boreal forest region. Therefore, assuming a $10 \%$ increase in the $\mathrm{CCN}$ formation process, $c_{\mathrm{CCN}}$ will increase by $3-6 \%$. This will subsequently increase the optical thickness of individual clouds by $1-$ $2 \%$, resulting in an increase in reflection of sunlight back to space. Note that the maximum increase in $c_{\mathrm{CCN}}$ may even be close to $100 \%$ if doubled atmospheric $\mathrm{CO}_{2}$ concentration also leads to doubled BVOC emission rates (the extreme case of complete coupling). Then the optical thickness of individual clouds could increase even by $20 \%$. According to a recent order-of-magnitude estimation, the contribution of boreal aerosol formation to the global radiative balance is -0.03 to $-1.1 \mathrm{Wm}^{-2}$ (Kurtén et al., 2003). Therefore, assuming a $10 \%$ increase in $c_{\mathrm{CCN}}$, the total contribution by $\mathrm{CCN}$ to the radiative balance will also increase by $10 \%$. It is worth noting, though, that the cooling effect of a $10 \%$ increase in $\mathrm{CCN}$ is rather small compared to warming by a doubling of $\mathrm{CO}_{2}$.

\section{Conclusions}

The results indicate two important connections in terms of seasonal variability, one between the growth rate of nucleation-mode aerosol particles and ecosystem gross primary production, and another between the formation rate of nucleation-mode particles and the ozonolysis of terpenoids. In addition, the seasonal pattern of particle growth rates is similar to that of the formation of oxidation products from terpene reactions with $\mathrm{OH}$ radicals. The proposed interaction between forest ecosystems, BVOC emissions, aerosol formation and clouds emphasizes the significance of forests on climate change. Thus forests, in addition to being sinks of $\mathrm{CO}_{2}$, also act as sources for aerosol particles. For both of these reasons, increased forest growth leads to the slowing down of global warming. For more quantitative estimations, laboratory experiments, global climate modelling, and extensive international measurement campaigns are necessary.

Edited by: B. Conant

\section{References}

Aalto, P., Hämeri, K., Becker, E., Weber, R., Salm, J., Mäkelä, J.M., Hoell, C., O’Dowd, C.D., Karlsson, H., Hansson, H.-C., Väkevä, M., Koponen, I.K., Buzorius, G., and Kulmala, M.: Physical characterization of aerosol particles during nucleation events, Tellus, 53B, 344-358, 2001.

Atkinson, R.: Atmospheric chemistry of VOCs and $\mathrm{NO}_{\mathrm{x}}$, Atmosph. Env., 34, 2063-2101, 2000.

Bäck, J., Juurola, E., Hari, P., Hakola, H., Reissell, A., and Kulmala, M.: The dynamics of terpenes in Scots pine needles, In Proceedings of ILEAPS Open Science Conference, Helsinki, Finland, edited by Korhonen, H., Arneth, A., Kulmala, M., Raivonen, M., Ruuskanen, T., and Suni, T., Finnish Association for Aerosol Research, 53, 2003.

Birmili, W. and Wiedensohler, A.: New particle formation in the continental boundary layer: Meteorological and gas phase parameter influence, Geophys. Res. Lett., 27, 3325-3328, 2000.

Bohlmann, J., Meyer-Gauen, G., and Croteau, R.: Plant terpenoid synthases: molecular biology and phytogenetic analysis, Proceedings of the National Academy of Science, USA, 95, 41264133, 1998.

Bonn, B. and Moortgat, G. K.: Sesquiterpene ozonolysis: Origin of atmospheric new particle formation from biogenic hydrocarbons, Geophys. Res. Lett., 30, 1585-1588, 2003.

Boy, M., Rannik, Ü., Lehtinen, K. E. J., Tarvainen, V., Hakola, H., and Kulmala, M.: Nucleation events in the continental boundary layer: Long-term statistical analyses of aerosol 
relevant characteristics, J. Geophys. Res., 108(D21), 4667, doi:10.1029/2003JD003838, 2003.

Calogirou, A., Larsen, B. R., and Kotzias, D.: Gas-phase terpene oxidation products: a review, Atmosph. Env., 33, 1423-1439, 1999.

Coe, H., Williams, P. I., McFiggans, G., Gallagher, M. W., Beswick, K. M., Bower, K. N., and Choularton, T. W.: Behaviour of ultrafine particles in continental and marine air masses at a rural site in the United Kingdom, J. Geophys. Res., 105 D, 26 891-26905, 2000.

Farquhar, G. D. and von Caemmerer, S.: Modelling of photosynthetic response to environmental conditions. In Physiological Plant Ecology II, Encyclopedia of Plant Physiology New Series (edited by Ziegler, O. L. et al.), 550-587, Springer-Verlag, Berlin, 1982.

Fuentes, J. D., Lerdau, M., Atkinson, R., Baldocchi, D., Bottenheim, J. W., Ciccioli, P., Lamb, B., Geron, C., Gu, L., Guenther, A., Sharkey, T. D., and Stockwell, W.: Biogenic hydrocarbons in the atmospheric boundary layer: A review, Bulletin of the American Meteorological Society, 81, 1537-1575, 2000.

Grace, J. and Rayment, M.: Respiration in the balance, Nature, 404, 819-820, 2000

Gu, L., Baldocchi, D. D., Wofsy, S. C., Munger, J. W., Michalsky, J. J., Urbanski, S. P., and Boden, T. A.: Response of a Deciduous Forest to the Mount Pinatubo Eruption: Enhanced Photosynthesis, Science, 299, 2035-2038, 2003.

Guenther, A., Hewitt, C. N., Ericson, D., Fall, R., Geron, C., Graedel, T., Harley, P., Klinger, R., Lerdau, M., McKay, W. A., Pierce, T., Scholes, R., Steinbrecher, R., Tallamraju, R., Taylor, J., and Zimmerman, P.: A model of natural volatile organic compound emissions, J. Geophys. Res., 100, 8873-8892, 1995.

Hakola, H., Laurila, T., Lindfors, V., Hellen, H., Gaman, A., and Rinne, J.: Variation of the VOC emission rates of birch species during the growing season, Boreal Env. Res., 6, 237-249, 2001.

Hakola, H., Tarvainen, V., Laurila, T., Hiltunen, V., Hellen, H., and Keronen, P.: Seasonal variation of VOC concentrations above a boreal coniferous forest, Atmosph. Env., 37, 1623-1634, 2003.

Hari, P. and Mäkelä, A.: Annual pattern of photosynthesis in Scots pine in the boreal zone, Tree Physiology, 23, 145-155, 2003.

Hoffmann, T., Bandur, R., Marggraf, U., and Lindscheid, M.: Molecular composition of organic aerosols formed in the alphapinene $-\mathrm{O}_{3}$ reaction: implications for new particle formation processes, J. Geophys. Res., 103, 25 569-25 578, 1998.

Janson, R. W.: Monoterpene emissions from scots pine and norwegian spruce, J. Geophys. Res., 98, 2839-2850, 1993.

Kanakidou, M., Tsigaridis, K., Dentener, F., and Crutzen, P.: Human-activity-enhanced formation of organic aerosols by biogenic hydrocarbon oxidation, J. Geophys. Res., 105, 9243-9254, 2000.

Kavouras, I. G., Mihalopoulos, N., and Stephanou, E. G.: Formation of atmospheric particles from organic acids produced by forests, Nature, 395, 686-693, 1998.

Kulmala, M., Pirjola, L., and Mäkelä, J. M.: Stable sulphate clusters as a source of new atmospheric particles, Nature, 404, 66-69, 2000.

Kulmala, M., Hämeri, K., Aalto, P., Mäkelä, J., Pirjola, L., Nilsson, E. D., Buzorius, G., Rannik, Ü., Dal Maso, M., Seidl, W., Hoffmann, T., Jansson, R., Hansson, H.-C., O’Dowd, C., and Viisanen, Y:: Overview of the international project on biogenic aerosol formation in the boreal forest (BIOFOR), Tellus B, 53, 324-343, 2001.

Kulmala, M., Vehkamäki, H., Petäjä, T., Dal Maso, M., Lauri, A., Kerminen, V.-M., Birmili, W., and McMurry, P. H.: Formation and growth rates of ultrafine atmospheric particles: a review of observations, J. Aerosol Sci., 35, 143-176, 2004.

Kurtén T., Kulmala, M., Dal Maso M., Suni T., Reissell A., Vehkamäki H., Hari P., Laaksonen A., Viisanen Y., and Vesala T.: Estimation of different forest-related contributions to the radiative balance using observations in southern Finland, Boreal Env. Res., 8, 275-285, 2003.

Lenton, T. M.: Land and ocean carbon cycle feedback effects on global warming in a simple Earth system model, Tellus, 52B, 1159-1188, 2000.

Lichtenthaler, H. K.: The 1-deoxy-d-xylulose-5-phosphate pathway of isoprenoid biosynthesis in plants, Annual Review of Plant Physiology and Plant Molecular Biology, 50, 47-65, 1999.

Loreto, F., Ciccioli, P., Cecinato, A., Brancaleoni, E., Frattoni, M., and Sharkey, T.: Different sources of redunced carbon contribute to form three classes of terpenoid emitted by Quercus ilex L. leaves, Proceedings of the National Academy of Sciences, USA, 93, 9966-9969, 1996.

Markkanen, T., Rannik, Ü., Keronen, P., Suni, T., and Vesala, T.: Eddy covariance fluxes over a boreal Scots pine forest, Boreal Env. Res., 6, 65-78, 2001.

Mäkelä, J. M., Aalto, P., Jokinen, V., Pohja, T., Nissinen, A., Palmroth, S., Markkanen, T., Seitsonen, K., Lihavainen, H., and Kulmala, M.: Observations of ultrafine aerosol particle formation and growth in boreal forest, Geophys. Res. Lett., 24, 1219-1222, 1997.

Mäkelä, J. M., Hoffmann, T., Holzke, C., Väkevä, M., Suni, T., Mattila, T., Aalto, P. P., Tapper, U., Kauppinen, E. I., and O’Dowd, C. D.: Biogenic iodine emissions and identification of end-products in coastal ultrafine particles during nucleation bursts, J. Geophys. Res., 107, D19, 10.1029/2001JD000580, 2002.

Nemani, R. R., Keeling, C. D., Hashimoto, H., Jolly, W. M., Piper, S. C., Tucker, C. J., Myneni, R. B., and Running, S. W.: Climatedriven increases in global terrestrial net primary production from 1982 to 1999, Science, 300, 1560-1563, 2003.

Nilsson, E. D., Rannik, Ü., Kulmala, M., Buzorius, G., and O'Dowd, C.: Effects of the continental boundary layer evolution, convection, turbulence and entrainment on aerosol tormation, Tellus, 53B, 441-461, 2001.

O’Dowd, C. D., Aalto, P., Hämeri, K., Kulmala, M., and Hoffmann, T.: Atmospheric particles from organic vapours, Nature, 416, 497-498, 2002.

Ottander, C., Campbell, D., and Öquist, G.: Seasonal changes in photosystem II organisation and pigment composition in Pinus sylvestris, Planta, 197, 176-183, 1995.

Schürmann W., Kotzias, D., Schönwitz, R., and Steinbrecher, R.: Emission of biosynthesized monoterpenes from needles of Norway spruce, Naturwissenschaften, 80, 276-278, 1993.

Seinfeld, J. H. and Pandis, S. N.: Atmospheric Chemistry and Physics: From Air Pollution to Climate Change Wiley, New York, 1998.

Staudt, M. and Bertin, N.; Light and temperature dependence of the emission of cyclic and acyclic monoterpenes from holm oak (Quercus ilex L.) leaves, Plant, Cell and Environment, 21, 385$395,1998$. 
Suni, T., Rinne, J., Reissell, A., Altimir, N., Keronen, P., Rannik, Ü., Dal Maso, M., Kulmala, M., and Vesala, T.: Long-term measurements of surface fluxes above a Scots pine forest in Hyytiälä, southern Finland, 1996-2001, Boreal Env. Res., 8, 287-301, 2003.
Vesala, T., Haataja, J., Aalto, P., Altimir, N., Buzorius, G., et al.: Long-term field measurements of atmosphere-surface interactions in boreal forest ecology, micrometeorology, aerosol physics and atmospheric chemistry, Trends in Heat, Mass and Momentum Transfer, 4, 17-35, 1998. 